\title{
The South Asian Shipbreaking Industry and its Unsafe Mining Practices
}

ISSN: 2578-0255

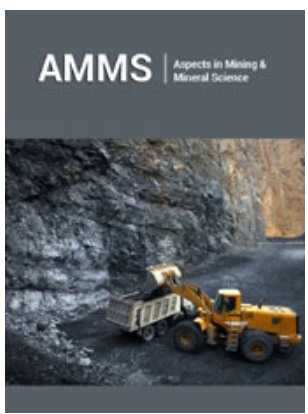

*Corresponding author: Prafula Pearce, Associate Professor (Law), Edith Cowan University, Perth, Australia

Submission: 侮 May 15, 2020

Published: 湝June 30, 2020

Volume 5 - Issue 2

How to cite this article: Mohammad Zulfikar Ali, Prafula Pearce. The South Asian Shipbreaking Industry and its Unsafe Mining Practices. Aspects Min Miner Sci. 5(2). AMMS.000607. 2020. DOI: 10.31031/AMMS.2020.05.000607

Copyright@ Prafula Pearce, This article is distributed under the terms of the Creative Commons Attribution 4.0 International License, which permits unrestricted use and redistribution provided that the original author and source are credited.

\author{
Mohammad Zulfikar Ali ${ }^{1}$ and Prafula Pearce ${ }^{2 *}$ \\ ${ }^{1} \mathrm{PhD}$ in Law Candidate, Curtin Law School, Perth, Australia \\ ${ }^{2}$ Associate Professor (Law), Edith Cowan University, Perth, Australia
}

\section{Opinion}

In the last two decades, India, Bangladesh and Pakistan have been the market leaders for breaking ships ${ }^{1}$. Before 2000, developed countries had their own shipbreaking industries. Due to risks involved in the process and the high level of safety standards under their established laws, it became too expensive to retain the shipbreaking industry in the developed countries. By the end of $20^{\text {th }}$ century, shipbreaking was gradually shifted mainly to Turkey, China, India, Bangladesh and Pakistan ${ }^{2}$. At present, China and Turkey have higher shipbreaking costs than South Asia and therefore Turkey and China have not been the preferred destinations for the last ten years. The reason for this is that Turkey's labour cost is twenty-five times higher than Bangladesh and India (around \$17.52 per day in Turkey compared to less than $\$ 1$ in Bangladesh per day) ${ }^{3}$. China on the other hand has invested a large amount of capital in building dry docks for shipbreaking ${ }^{4}$, whereas India, Bangladesh and Pakistan have low cost of labour, and they use the cheaper beaching method instead of dry dock ${ }^{5}$. Dry dock is expensive but causes less environmental damage as wastes can be removed safely from the ships ${ }^{6}$. In contrast, the beaching method of shipbreaking is cheaper in terms of establishment costs, but is a major concern for a sustainable shipbreaking as it allows toxic substances to escape directly into the seawater. By using the cheaper beaching method and combined with the low cost of labour, the three South Asian countries control 90\% the global shipbreaking business. In fact, the price offered to shipping companies by India, Bangladesh and Pakistan differs significantly from the price offered by Turkey and China ${ }^{7}$. A large container ship that weighs around 25,000 Light

${ }^{1}$ NGO Shipbreaking Platform, 'Platform Publishes List of Ships Dismantled Worldwide in 2018' (Press release, online at January 30, 2019) https://www.shipbreakingplatform.org/ platform-publishes-list-2018/ ('Press Release').

${ }^{2}$ Saiful Karim, Shipbreaking in Developing Countries: A Requiem for Environmental Justice from the Perspectives of Bangladesh (Taylor and Francis Group, 2018) 104.

${ }^{3}$ Turkey National Minimum Wage' Countryeconomy.com (online) https://countryeconomy. com/national-minimum-wage/turkey; 'Bangladesh Minimum Wage, Labour Law, and Rate 2019, Employment Data Sheet Bangladesh Minimum Wage' Minimum Wage.org (online) https://www.minimumwage.org/international/bangladesh.

${ }^{4}$ Matt Miller, Shipbreaking: Breaking Badly (Web Page, April 23, 2018) http://www.ajot. com/news/channel/maritime.

${ }^{5}$ Beaching means breaking ships on open beaches without any built structure. During high tide, a crewmember runs a ship on an open beach at its top speed so that it reaches as far as possible to the top end of a beach. After this, the unskilled workers strip, and dismantle the ship. Since the method uses a beach to break a ship, it is not possible to install any modern equipment for breaking and therefore the internal materials are directly released into the seawater. On the other hand, dry dock means to break ships inside of a built structure with all modern facilities to release and manage the internal wastes of a ship.

${ }^{6}$ Dry docks is a built structure used for breaking ships so that hazardous substances can be managed in a sound way that stops such materials from mixing with sea water.

${ }^{7}$ Robin Des Bois, 'Shipbreaking Bulletin of Information and Analysis of Ship Demolition' (Report no. 52, July 31, 2018) 13. 
Displacement Tonnages (LDTs) ${ }^{8}$ can earn a shipping company about $\$ 11.80$ million from a ship purchased by India, but only $\$ 7$ million from Turkey and $\$ 5.25$ million from China9 ${ }^{9}$ In 2018, the three South Asian countries jointly broke 518 ships out of total 744 ships that had been broken worldwide. In terms of LDT, this amounts to $90.4 \%$ of ships that required breaking ${ }^{\mathbf{1 0}}$. The shipbreaking industry is an economic necessity for the South Asian countries. These countries rely on the shipbreaking industry for their principal source of steel scraps and generate employment for their people. It contributes to $10-15 \%$ of overall steel production of India and Pakistan and $60 \%$ for Bangladesh ${ }^{11}$. The profit from breaking one ship in Pakistan is $\$ 16,600$ and $\$ 921,400$ in Bangladesh ${ }^{12}$. The high profit that is generated from the shipbreaking materials makes a significant contribution towards the government tax revenues. For example, the Bangladesh government earns about $\$ 86$ million per year as tax revenue from the shipbreaking industry ${ }^{\mathbf{1 3}}$. In 2016, about $15 \%$ of the total tax revenue of Bangladesh came from their shipbreaking industry ${ }^{14}$.

A significant number of workers are also employed in the South Asian shipbreaking industry. A World Bank Report in 2010 identified that over 40,000 workers were directly employed in the shipbreaking yards in Bangladesh and Pakistan. The Indian shipbreaking industry employs about 66,000 workers $^{15}$. In 2017 , more than 25,000 workers were directly employed in the Bangladesh shipbreaking industry ${ }^{16}$. In addition, more than one million people are employed in retail shops and re-rolling mills that are dependent on the shipbreaking industry. However, these economic benefits come at a cost to the environmental and human rights of workers. This is mainly due to their unsafe practices that are not appropriately regulated. The workers employed in the South Asian shipbreaking industry have minimum experience on sound management and safety, and these workers undertake risky shipbreaking processes ${ }^{17}$ without following the required high level of environmental and technical standards. According to the World Bank, there are three main unsafe practices within the South Asian shipbreaking industry ${ }^{18}$. Firstly, the shipowners send their ships to India, Bangladesh or Pakistan without pre-cleaning the toxic materials that remain in the old ships ${ }^{19}$. They mainly use the practice of reflagging to avoid their national and international responsibility of pre-cleaning ${ }^{20}$. Reflagging means to change the flag of a state to some particular states using open registries ${ }^{21}$. Open registry of a state permits shipowners to register a vessel in a particular flag state without its own nationality. For example, the States of Panama and Liberia allow open registry for a fee. One report shows that $73 \%$ of world ships are registered under a country other than its beneficial and original owner ${ }^{22}$. These are referred to as Flag of Convenience states (FOCs). FOCs have poor legal requirement on pre-cleaning ${ }^{23}$. Therefore, these old vessels often fly a flag of FOCs before reaching the shipbreaking yard and often remain polluted with toxic substances, such as Polychlorinated Biphenyls (PCBs), asbestos, lead paints, mercury, fuel deposits, and other harmful substances. Secondly, when the ships reach the territorial water, they are run aground on the beaches at full speed during high tide. After beaching, the ships are cleaned on shallow open beaches, often near mangrove swamps. By using this method, they discharge

${ }^{8}$ Dictionary meaning of Light Displacement Tonnage is the weight of a ship with all its permanent equipment excluding the weight of cargoes, persons, fuel, dunnage and ballast. It is also referred to as gross tonnage: at dictionary.com (online at 26 June, 2019) https://www.dictionary.com/browse/light-displacement.

Ibid.

${ }^{10}$ Press Release (n 10); NGO Shipbreaking Platform News, Use of Polluting South Asia Scrap Yards Accelerating (Web Page, 1 February 2017) http://gcaptain.com/ngo-shipbreaking-platform-use-of-polluting-south-asia-scrap-yardsaccelerating/.

${ }^{11}$ Maria Sarraf et al, 'Ship Breaking and Recycling Industry in Bangladesh and Pakistan,' (Report No. 58275-SAS, World Bank, 2010) 1-5 ('World Bank Report 2010').

${ }^{12}$ Ibid.

${ }^{13}$ N. M. Golam Zakaria, Mir Tareque Ali and Khandakar Akhter Hossain, 'Underlying Problems of Ship Recycling Industries in Bangladesh and Way Forward' (2012) 9 (2) Journal of Naval Architecture and Marine Engineering $91,98$.

${ }^{14}$ Hasan Ruhan Rabbi and Aevelina Rahman, 'Shipbreaking and Recycling Industries in Bangladesh; Issues and Challenges' (2017) 194 Prodcedia Engineering 254, 256.

${ }^{15}$ Amit B. Mahindrakar et al, 'Shipbreaking industry in India: Assessment of Opportunity and Challenges' (January 2008) eLaw Journal: Journal of Air and Waste Management Association 1.

${ }^{16}$ Hossain et al (n 14).

${ }^{17}$ Robert Scott Frey, 'Breaking Ships in the World-System: An Analysis of Two Ships Breaking Capitals, Alang-Sosiya, India and Chittagong, Bangladesh' (2015) 21 (1) Journal of World Systems Research 26, 28.

${ }^{18}$ World Bank Report 2010 (n 20) 31-38.

${ }^{19}$ Pre-cleaning means the process of discharging all contaminated items of a ship by the shipping companies or the owners before sending them for dismantling.

${ }^{20} \mathrm{Juan}$ Ignacio Alcadidea, Francisco Piniella and Emilio Rodriguez-Diaza, 'The Mirror Flags: Ship Registration in Globalised Shipbreaking Industry’ (2016) 48 Transportation Research Part D, 378.

${ }^{21}$ Rhea Rogers, 'Ship Registration: A Critical Analysis' (LLM Dissertation, World Maritime University, 2010$) 28$.

${ }^{22}$ NGO Shipbreaking Platform, Flag of Convenience (Web Page) https://www.shipbreakingplatform.org/issues-ofinterest/focs /

${ }^{23}$ Ibid. 
all toxic substances into the seawater ${ }^{24}$, resulting in air pollution, soil erosion, soil contamination and water pollution, contamination of coastal regions and loss of biodiversity. The release of toxic waste has an impact on mangrove forests and threatens its habitat ${ }^{25}$. Examples of such polluted locations of shipbreaking industry are the 'toxic hotspots' or 'sacrifice zones' in Alang of India, Sitakunda of Bangladesh and Gadani of Pakistan ${ }^{26}$. Thirdly, ships are broken by using dangerous manual methods such as cutting ships with oxy-fuel torch and workers often carry steel plates on their shoulder. Such practices cause frequent accidents leading to death and injuries to the workers. Statistics show the following reasons as causes of accidents: fire explosions due to unseen gas in the ship chamber (49\%); the fall of plates and parts of ships in the process of scrapping (25\%); inhalation of toxic gas (16\%) and workers falling from ships $(8 \%)^{27}$.

A report from International Metalworkers Federation states, "Shipbreaking is one of the most dangerous occupations"28. This is also evident from various non-profit organization (NGO) reports. In November 2016, at least 28 workers died, and more than 50 workers suffered injuries due to explosion in a ship beached in Gadani, Pakistan. In 2016, 22 deaths and 29 serious injuries of workers were reported in Bangladesh. In India, two people died by a fatal accident ${ }^{29}$. In the first quarter of 2018, ten workers lost their lives, and two workers had severe injuries in Bangladesh. At a shipbreaking yard in Alang, India, at least two workers lost their lives due to a toxic gas leak ${ }^{30}$. Further, on 18th February 2019, two shipbreaking workers were killed at a shipbreaking yard in Bangladesh ${ }^{31}$. Literature in this area indicates that neither the international community nor the shipping companies have taken responsibility of the problems caused in the shipbreaking industry ${ }^{32}$. Shipping companies do not want to bear the high cost of safe and proper disposal of the ships. Developing countries lack the resources required to upgrade their standards in shipbreaking. Thus, unless all parties involved in the shipbreaking industry are regulated through an international regulatory regime, the problems identified will remain. International conventions such as the Basel Convention and the Hong Kong Convention have not succeeded in changing this dangerous South Asian shipbreaking industry. A global solution is required and is yet to be found.

${ }^{24}$ Gopal Krishna, 'High on Hazard, Alang Poses Big Threat to Environment and Health of Local Communities, Migrant Workers', Financial Chronicle (online at 21 December 2012) http://www.mydigitalfc.com/industry/high-hazard-463> provides that beaching means anchoring ships on sandy beaches for dismantling. It is a traditional method of bringing ships as close as possible to the intertidal zones of coastal areas. This helps them to cut ships without using built structures, except the hull of a ship.

${ }^{25}$ Mohammad Maruf Hussain and Mohamamad Mahmudul Islam, 'Ship Breaking Activities and Its Impact on the Coastal Zone of Chittagong, Bangladesh: Towards Sustainable Development' (Research Report, Young Power in Social Action, Chittagong, Bangladesh, 2006); Federico Demaria, 'Shipbreaking at Alang-Sosiya (India): An Ecological Distribution Conflict' (2010) 70 Ecological Economics 250, 252-254.

${ }^{26}$ Frey (n 17) 27.

${ }^{27}$ Zakaria, Ali and Hossain (n 13) 98.

${ }^{28}$ International Metalworkers Federation, Special Report-Cleaning Up Shipbreaking is the Most Dangerous of the World (Web Page, 15 December 2015) http://www.industriall-union.org/cleaning-up-ship-breaking-the-worlds-mostdangerous-job.

${ }^{29}$ Michael Schuler, NGO Shipbreaking Platform News: Use of Polluting South Asia Scrap Yards Accelerating (Web Page, 1 February 2017) http://gcaptain.com/ngo-shipbreaking-platform-use-of-polluting-south-asia-scrap-yardsaccelerating/.

${ }^{30}$ NGO Shipbreaking Platform, Waste Management World- Europe's Toxic Ships: How Poor Recycling Practices are Poisoning Asian Beaches (Web Page, 16 August 2013) http://www.shipbreakingplatform.org/waste-managementworld-europes-toxic-ships-how-poor-recycling or shipbreaking-practices-are-poisoning-asian-beaches /.

${ }^{31}$ NGO Shipbreaking Platform, 'Fire on Board Greek Tanker Kills two Shipbreaking Workers in Bangladesh' (Press Release, 18 February 2019) 1.

${ }^{32}$ Karim (n 2) 25. 